\title{
HISTORICAL AND GEOGRAPHICAL PATTERNS IN KNEMIDOKOPTES MITE INFESTATIONS IN SOUTHERN CALIFORNIA BIRDS
}

\author{
KEVIN B. CLARK, San Diego Natural History Museum, P. O. Box 121390, San \\ Diego, California 92112; kclark@sdnhm.org \\ BRUCE RIDEOUT, Zoological Society of San Diego, P. O. Box 120551, San Diego, \\ California 92112
}

KIMBALL L. GARRETT, Natural History Museum of Los Angeles County, 900 Exposition Blvd., Los Angeles, California 90007

PHILIP UNITT, San Diego Natural History Museum, P. O. Box 121390, San Diego, California 92112

BARRY OCONNOR, Museum of Zoology, University of Michigan, 1109 Geddes Ave., Ann Arbor, Michigan 48109

\begin{abstract}
We investigated the causes of toe and foot loss and other deformities long observed in urban Brewer's Blackbirds (Euphagus cyanocephalus) in southern California. Histopathologic evaluation showed that afflicted individuals suffered from infestations of mites compatible with Knemidokoptes spp. (scaly-leg mites). We developed a case definition based on gross lesions in confirmed cases and the scientific literature to search two large ornithological collections for specimens exhibiting these lesions. In evaluating specimens among seven species of the family Icteridae, we found 34 specimens in the two collections with lesions consistent with Knemidokoptes spp. Species afflicted included the Red-winged Blackbird (Agelaius phoeniceus; 12 of 978 specimens), Brewer's Blackbird (10/337 specimens), Tricolored Blackbird (A. tricolor; 4/101 specimens), Brown-headed Cowbird (Molothrus ater; 4/828 specimens), and Great-tailed Grackle (Quiscalus mexicanus; 4/224 specimens). The earliest cluster of California specimens dated to 1962 . Fourteen of the 34 specimens exhibiting the condition were collected since 1999. No specimens of the Yellow-headed Blackbird (Xanthocephalus xanthocephalus; 0 of 214 specimens) or Western Meadowlark (Sturnella neglecta; 0/278) were found with the condition.
\end{abstract}

Flocking blackbirds of the genera Agelaius, Molothrus, Euphagus, and Quiscalus are generally abundant and highly visible members of local avifaunas. As such, they are excellent candidates or sentinel species for tracking the occurrence of disease in local bird populations. In the past several years, a noticeable prevalence of toe and foot loss and other foot deformities among urban Brewer's Blackbirds (Euphagus cyanocephalus) in southern California has resulted in public concern and media attention to this condition (e.g., Brennan 2013, Figure 1). We investigated the causes of this condition through histopathologic evaluation of several recently collected blackbirds. We also searched the collections of the Natural History Museum of Los Angeles County and San Diego Natural History Museum to locate specimens showing lesions consistent with those found in local wild populations, to investigate the geographical and temporal patterns of this condition.

One of the more prevalent but poorly understood ectoparasites afflicting wild bird populations worldwide is Knemidokoptes, a genus of mites (Acari; Astigmata; Epidermoptidae), commonly associated with proliferative lesions on the shanks of free-ranging backyard chickens. In birds, infestations of these mites can cause a condition known as scaly-leg (Turk 1950), because 


\section{PATTERNS IN KNEMIDOKOPTES MITE INFESTATIONS}

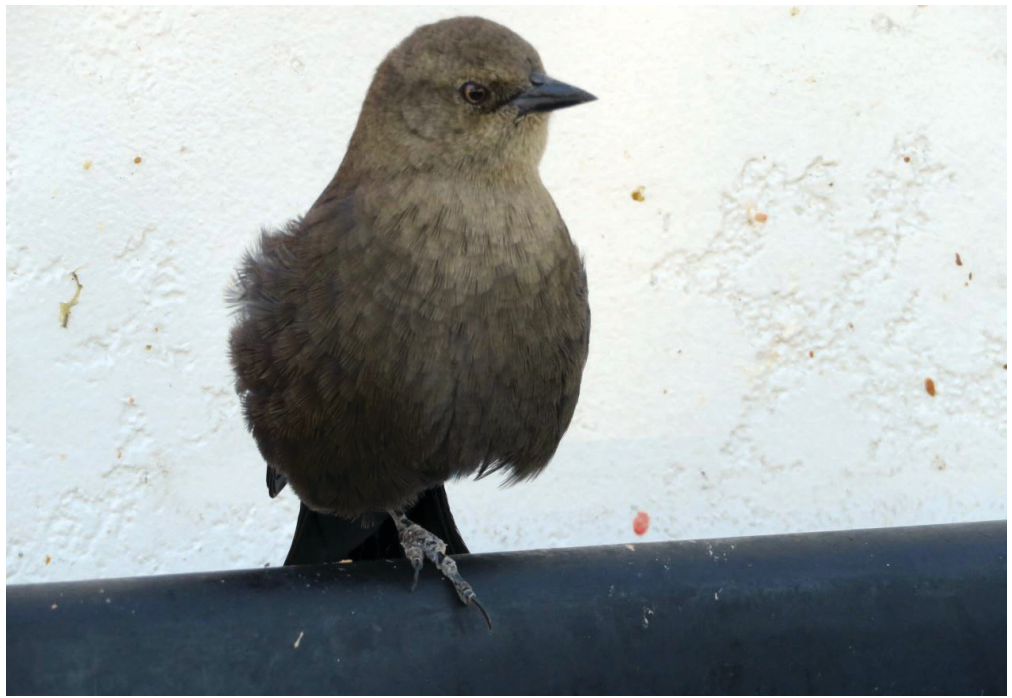

Figure 1. Female Brewer's Blackbird in urban San Diego showing a missing toe and typical hyperkeratotic lesions due to Knemidokoptes.

Photo by Kevin B Clark

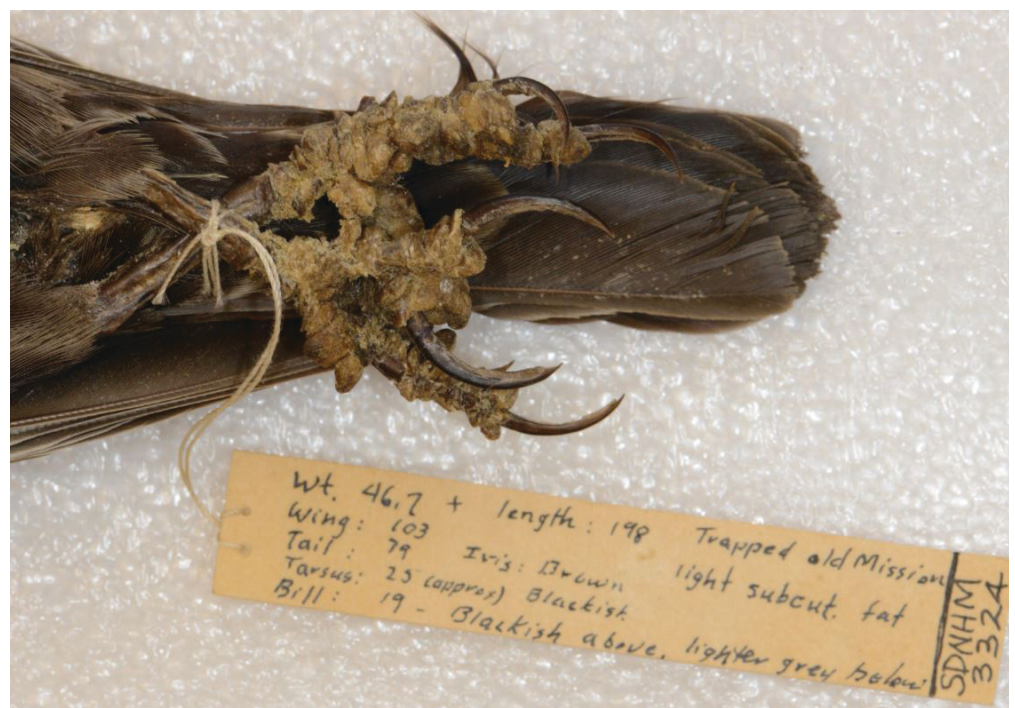

Figure 2. Red-winged Blackbird museum specimen with typical hyperkeratotic lesions due to Knemidokoptes.

Photo by Bruce Rideout 
the mites induce a remarkable hyperkeratosis and thickening of the scales on the anterior portions of the legs.

These mites are typically transmitted through close proximity among roosting birds. Latta (2003) found that populations of birds that roost communally have higher rates of infection with Knemidokoptes, whereas those in which communal roosting is less prevalent have lower rates of infection.

\section{METHODS}

Complete postmortem exams were conducted on a selection of passerines submitted freshly dead to the San Diego Natural History Museum (SDNHM; $n$ $=5$ ) or through Project Wildlife, a wildlife-rehabilitation facility in San Diego County $(n=3)$. A complete representative set of tissues, including skin from legs and feet, was collected in 10\% neutral-buffered formalin and processed routinely. Tissues were sectioned at $5 \mu \mathrm{m}$, stained with hematoxylin and eosin, and evaluated by light microscopy by a board-certified veterinary pathologist (Rideout). A diagnosis of Knemidokoptes spp. infection was made when ectoparasites of appropriate size (300-400 $\mu \mathrm{m}$ in diameter) and shape (round in transverse section), with short jointed appendages and striated muscles, were found in skin sections exhibiting marked hyperkeratosis and scaling. A diagnosis of poxvirus infection was made when pathognomonic eosinophilic cytoplasmic inclusions (Bollinger bodies) were found in markedly hyperplastic epidermal squamous cells.

We screened the ornithological collections of the San Diego Natural History Museum (SDNHM, 50,000 specimens) and Los Angeles County Museum of Natural History (LACM, 100,000 specimens) for additional cases compatible with Knemidokoptes sp. infection. We defined a case, on the basis of gross lesions observed in histopathologically confirmed cases $(n=5)$ and descriptions in the literature (Herman et al. 1962, Pence et al. 1999), as any bird with grossly evident regional hyperkeratosis and scaling affecting unfeathered portions of the legs and feet (e.g., Figure 2). Toes or the entire foot may have been lost, but the nodular thickenings and inflammatory crust typically associated with poxvirus infections must be absent. It is likely that incipient infections were missed.

In order to verify the predictive value of this case definition, we collected skin samples from one museum specimen (Red-winged Blackbird, Agelaius phoeniceus) and one fresh necropsy case (American Robin, Turdus migratorius, San Diego Zoo RP24085) that met the case definition for histopathologic evaluation described above, and extracted mites by dissection from anterior tibiotarsal skin lesions softened with sterile saline. In the laboratory, mites were cleared in lactophenol, mounted in Hoyer's medium, and subsequently identified morphologically as Knemidokoptes jamaicensis Turk by OConnor, on the basis of morphologic features and measurements established by Fain and Elsen (1967). Voucher specimens from these hosts are deposited in the University of Michigan Museum of Zoology.

We limited our analysis of specimens to species of the family Icteridae for which over 100 specimens were available between the two museum collections. This sample encompassed seven species, the Yellow-headed Blackbird (Xanthocephalus xanthocephalus), Red-winged Blackbird, Tri- 
colored Blackbird (A. tricolor), Great-tailed Grackle (Quiscalus mexicanus), Brown-headed Cowbird (Molothrus ater), Brewer's Blackbird, and Western Meadowlark (Sturnella neglecta). Years of collection of the screened specimens ranged from 1886 to 2014 at LACM and 1876 to 2015 at SDNHM.

\section{RESULTS}

The mites extracted from both the fresh necropsy case and from the sample museum specimen were identified as Knemidokoptes jamaicensis. This mite species is prevalent in cases of scaly-leg keratosis in passerine birds in North America and other regions of the world (e.g., Kirmse 1966, Pence et al. 1999, Latta 2003, Munday 2006).

In the sample of 2960 specimens analyzed, we identified 34 (1.1\%) with scaly-leg conditions (Table 1). Ranked by the number of specimens showing scaly-leg conditions these species were the Red-winged Blackbird (12 specimens), Brewer's Blackbird (10), Brown-headed Cowbird (4), Tricolored Blackbird (4), and Great-tailed Grackle (4). No Yellow-headed Blackbirds or Western Meadowlarks were found with scaly-leg condition.

The findings from the two museum collection searches were highly concordant. The earliest scaly-legged specimen at LACM was a Red-winged Blackbird collected in 1962 in Orange County, California. The SDNHM contains four specimens of the Red-winged Blackbird and three of the Tricolored Blackbird showing scaly-leg conditions collected by Amadeo M. Rea at San Luis Rey in adjacent northern San Diego County, also in 1962. Of the 800 LACM and SDNHM specimens of the Red-winged Blackbird collected prior to 1962 that we evaluated, none from western North America had scaly-leg lesions.

Of the seven species of Icteridae examined, only one other California specimen with scaly-leg predates 1962: a Brown-headed Cowbird collected in 1924 along the Colorado River in Imperial County, California (SDNHM 9364). Of the three remaining pre-1962 specimens with scaly-leg lesions, two, both Red-winged Blackbirds, are from the eastern United States: a 1935 specimen from Monroe Co., Michigan (SDNHM 19115), and a 1926 specimen from Roswell, Georgia (SDNHM 26433). The final pre-1962 specimen, a Brewer's Blackbird collected at San Bruno, Baja California, Mexico, in 1930 (SDNHM 15669), is questionable for scaly-leg conditions.

Table 1 Prevalence of Scaly-Leg among Seven Southern California Icterid Species Archived in the Collections of the San Diego Natural History Museum and the Natural History Museum of Los Angeles County

\begin{tabular}{lccc}
\hline Species & $\begin{array}{c}\text { Number of } \\
\text { specimens with } \\
\text { scaly-leg }\end{array}$ & $\begin{array}{c}\text { Total number } \\
\text { of specimens } \\
\text { examined }\end{array}$ & Prevalence rate \\
\hline Red-winged Blackbird & 12 & 978 & $1.2 \%$ \\
Brewer's Blackbird & 10 & 337 & $3 \%$ \\
Tricolored Blackbird & 4 & 101 & $4 \%$ \\
Brown-headed Cowbird & 4 & 828 & $0.5 \%$ \\
Great-tailed Grackle & 4 & 224 & $1.8 \%$ \\
Yellow-headed Blackbird & 0 & 214 & 0 \\
Western Meadowlark & 0 & 278 & 0 \\
\hline
\end{tabular}


Fain and Elsen (1967) also reported a 1953 specimen of Brewer's Blackbird with scaly-leg from Pasadena, Los Angeles County.

Also notable is a Red-winged Blackbird collected from Santa Cruz Island in 1989 (SDNHM 46725), the only insular specimen with scaly-leg lesions we found. This condition has not been reported previously from the California Channel Islands, home to many endemic avian taxa.

After the Red-winged Blackbird, the species with next highest prevalence of scaly-leg lesions was Brewer's Blackbird. The ten Brewer's Blackbirds in the SDNHM with the condition were collected from 1968 to 2013, half since 2000. Though 237 Brewer's Blackbird specimens dated prior to 1968 are in the two collections, none clearly showed scaly-leg lesions. The five specimens found with the condition and collected since 2000 were among only 15 total specimens in the collections from that period (a 33\% prevalence).

Among all species examined, 14 of the total 34 specimens with clinical signs of scaly-leg had been collected since 1999 (41\% of the total), including specimens of the Brewer's Blackbird, Red-winged Blackbird, Tricolored Blackbird, and Great-tailed Grackle. The remaining 20 specimens spanned the period 1962-1999.

In addition to the species systematically searched in the collections, we found a few notable cases of Knemidokoptes mites among other species. These include a 2013 specimen of Cassin's Finch (Haemorhous cassinii; SDNHM 53926; Figures 3 and 4) from the San Jacinto Mountains in Riverside County and a 2007 specimen of the American Robin (SDNHM 51762) from urban San Diego. Also notable was a 2013 capture by Drew C. Stokes, incidental to mist-netting for bats, of a Spotted Towhee (Pipilo maculatus) in Camp Pendleton, northwestern San Diego County, with symptoms of severe mite infestation (www.inaturalist.org/observations/7605023).

We found males to be symptomatic at twice the rate of females (18 males vs. 9 females at SDNHM).

\section{DISCUSSION}

This paper presents the first temporal analysis of Knemidokoptes mite infestations in a defined geographical area. The apparently increasing prevalence of scaly-leg mites is concerning given recent population declines in some of the affected species. Brewer's Blackbird experienced a noticeable decline in abundance in southern California from the 1980s to the early 2000s (Unitt 2004), and that decline has continued since (Figure 5). While the role of scaly-leg mite infestation in causing a population decline is not clear, researchers have found correlations between mite infestation, body condition, and survivorship. Latta (2003) found a significant relationship between mite infestation and pectoral muscle scores, implicating mite infestations in weaker body condition. Latta also found that despite a return rate in successive years of $>60 \%$ in the two species of wintering warblers studied, no individual identified as having any level of Knemidokoptes infestation ever returned the following year. Benkman et al. (2005) found that survival of adult Red Crossbills (Loxia curvirostra) with mites was 15\% lower than that of adults without mites. Van Velden et al. (2017) found a decrease in nesting productivity associated with scaly-leg mite infestation. 


\section{PATTERNS IN KNEMIDOKOPTES MITE INFESTATIONS}

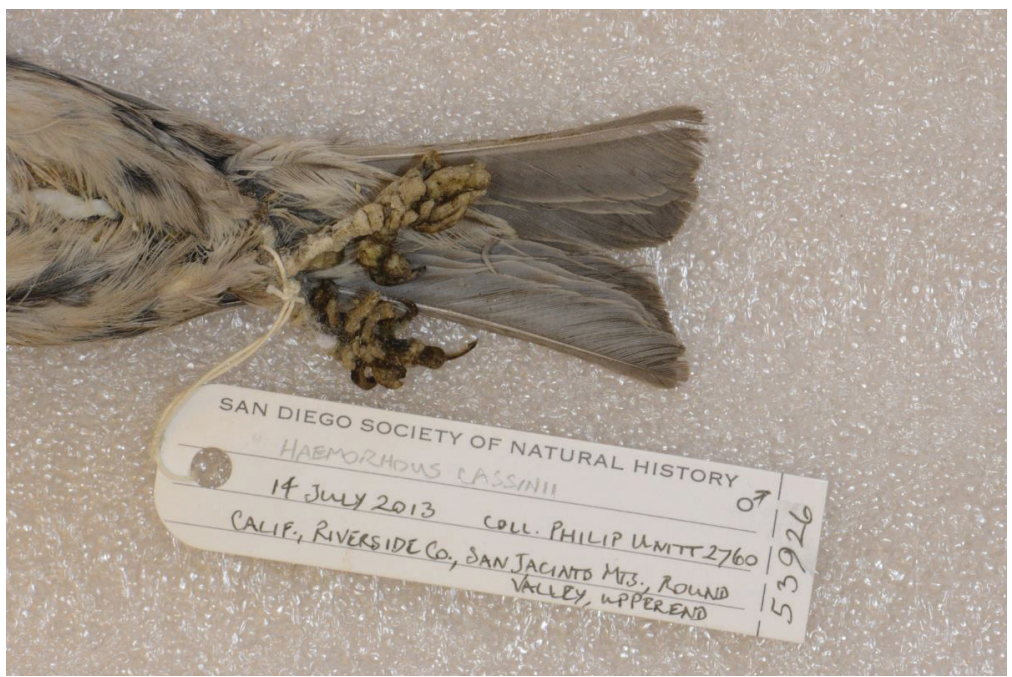

Figure 3. Recent Cassin's Finch museum specimen with hyperkeratotic lesions of Knemidokoptes.

Photo by Bruce Rideout

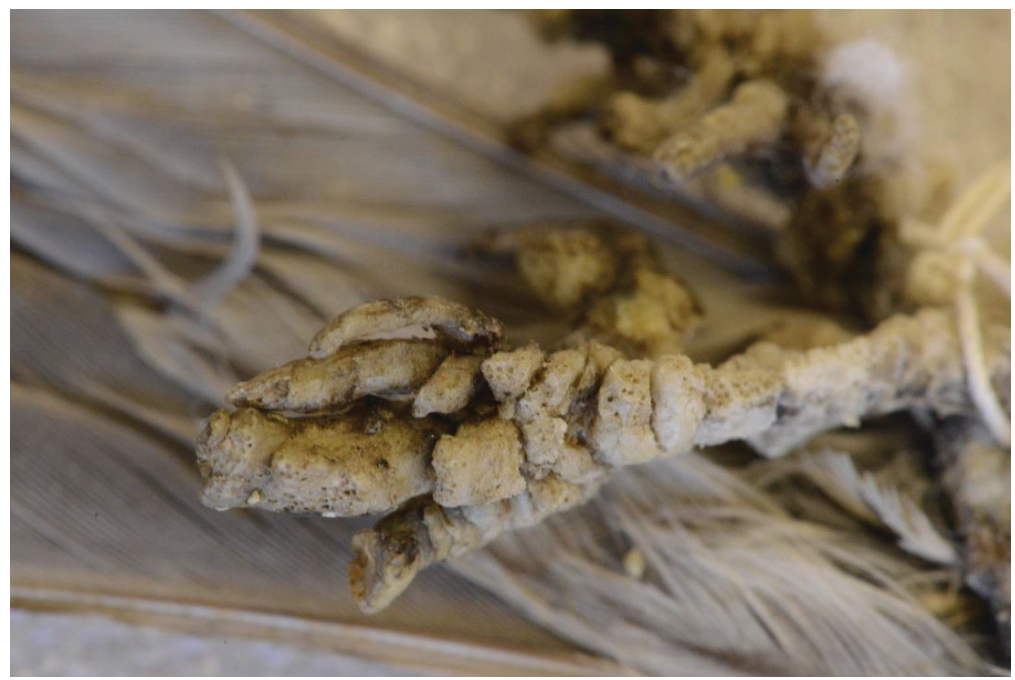

Figure 4. Close-up of the Cassin's Finch specimen showing mite tunnels in the thick keratin layers.

Photo by Bruce Rideout 


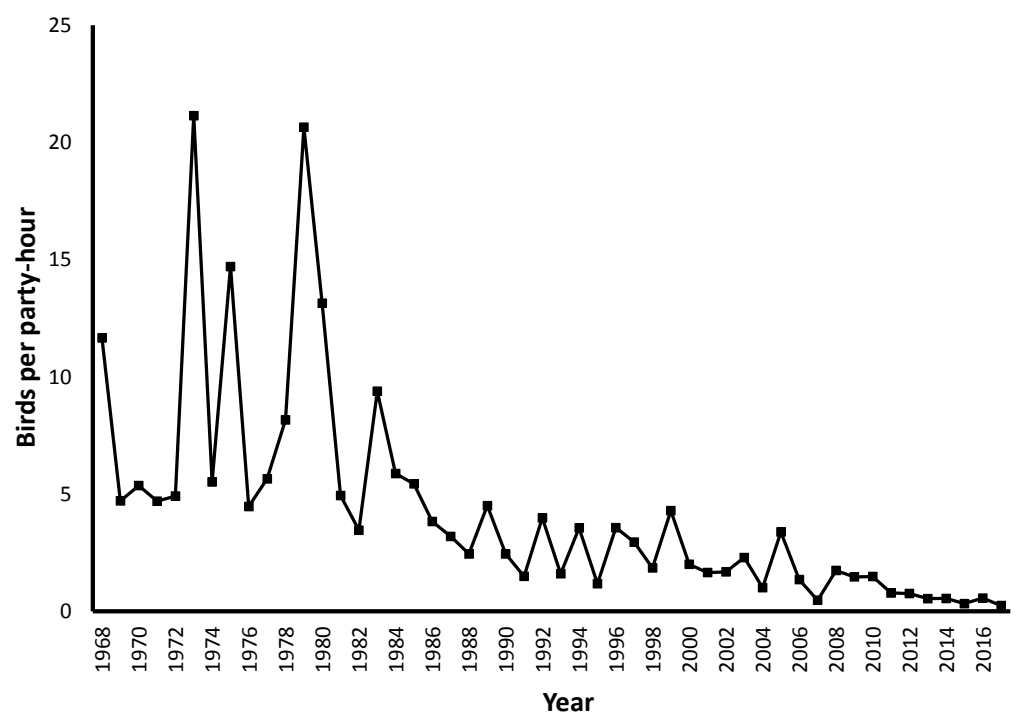

Figure 5. Occurrence of Brewer's Blackbird on the San Diego Christmas Bird Count, 1968-2017.

Although we found only four specimens of the Tricolored Blackbird with lesions of scaly-leg mite, this species had the highest rate of prevalence among the seven icterid species examined (4\%). That this rapidly declining species is susceptible to infestation is of concern. Though the specimens in the collections represented individuals from modest-sized southern California populations, individuals recently captured from large breeding aggregations in the Central Valley of California have exhibited scaly-leg lesions as well (B. Barnes, R. J. Meese pers. comm.).

The overall rate of $1.2 \%$ of Red-winged Blackbird specimens exhibiting scaly-leg mite conditions is less than the 4.3\% rate found in an analysis of 305 Red-winged Blackbird specimens from the Royal Ontario Museum (Kirmse 1966). Kirmse also reported rates in Red-winged Blackbirds wild-caught in marshes in Ontario ranging from 4 to $40 \%$.

The prevalence of scaly-leg mite we found in the Brown-headed Cowbird (0.5\%) is very similar to the rate of $0.6 \%$ found in an examination of over 8000 Brown-headed Cowbirds in Alabama (Stewart 1963). As in our sample, all cowbird specimens from Alabama showing the condition were males. Kirmse (1966) found a prevalence of scaly-leg mites in the Brownheaded Cowbirds in a marsh in Ontario, Canada, as high as 1.3\%.

The presence of the scaly-leg condition in a Red-winged Blackbird from Santa Cruz Island is also notable. This island harbors a number of endemic subspecies of birds, as well as the endemic Island Scrub-Jay (Aphelocoma insularis). While North American jays have not been reported to be afflicted with the scaly-leg mite, other corvids such as the Common Raven (Corvus corax) in Europe (Dabert et al. 2011), and the American Crow 
(Corvus brachyrhynchos; Pence 1972) have been reported as hosts of Knemidokoptes.

Carothers et al. (1974) reported a Cassin's Finch with scaly-leg at a feeding station in Flagstaff, Arizona, at a location with a high incidence of scaly-leg among resident Evening Grosbeaks (Coccothraustes vespertinus). The single Cassin's Finch with scaly-leg in the SDNHM collection was found in a natural area of Mount San Jacinto State Park, though only $6.5 \mathrm{~km}$ from the town of Idyllwild where numerous bird feeders are located.

While we are only aware of a single American Robin specimen from southern California exhibiting scaly-leg lesions, anecdotal observations of wild robins in the region with these symptoms indicate it is more common (Garrett pers. obs.). Pence et al. (1999) documented scaly-leg conditions in $60-80 \%$ of American Robins in several wintering flocks in Oklahoma.

We found males to exhibit scaly-leg symptoms more frequently than females (18 vs. 9 in SDNHM specimens). All specimens of the Tricolored Blackbird and Brown-headed Cowbird exhibiting the condition were males. Van Velden et al. (2017) found males to be more susceptible to scaly-leg mites in the Black Sparrowhawk (Accipiter melanoleucus) in South Africa. As male hawks, during the breeding season, do a majority of hunting for the mated pair and offspring, van Velden et al. (2017) speculated that one cause of the difference in incidence between the sexes may be greater opportunity for transmission from infected prey. But the icterids we studied do not prey upon birds, so Knemidokoptes must be transmitted among them through other mechanisms. The Brown-headed Cowbird is highly social, but it is unclear if there is a sexual difference in roosting behavior that would explain the difference in susceptibility. In southern California, some other urban species, such as the House Sparrow (Passer domesticus), appear to contract scaly-leg mites very rarely. We are aware of no House Sparrows observed or collected with the condition in the region, though they frequently associate with various blackbird species in urban situations. Nevertheless, in South Africa, Knemidokoptes jamaicensis has been identified in another urban adapter, the Cape Wagtail (Motacilla capensis) (Munday 2006).

While several recent and historic specimens were collected in remote locations, the recent trend in mite infestations seems to be an increased prevalence in human-modified landscapes. That sensitive and declining species, such as the Tricolored Blackbird, also mix with other blackbird species in these environments in the winter raises the question of whether this condition can be treated effectively in the wild. Among avian rehabilitators, this condition is reportedly readily treated with miticides (Maria Gonzalez pers. comm.). Methods for controlling outbreaks in specific locations could include baited trays of miticide-soaked pads over which these ground-foraging birds would walk.

That $41 \%$ (14 of 34) of the specimens found to show scaly-leg lesions were collected since 1999 implies that the prevalence of the condition in southern California is increasing, consistent with anecdotal observations (e.g., Brennan 2013). This sample includes 5 of 15 Brewer's Blackbirds in the collections within that period. Most of the older specimens were shot by collectors, so those individuals likely represent a more random sample than the recent specimens, most of which were received through wildlife rehabilitators and so presumably were more likely to be infected. The inci- 
dence of scaly-leg lesions in southern California needs better quantification, but the anecdotal evidence is considerable that the current incidence is likely high and increasing. For example, of six Red-winged Blackbirds trapped at Clover Flat in southeastern San Diego County in April 2018, two had obvious lesions (Unitt and Clark pers. obs.).

The reason for this increased prevalence is unclear. Van Velden et al. (2017) also reported an increased prevalence of this condition in recent decades in South Africa.

Two species analyzed did not show scaly-leg lesions. Both the Western Meadowlark and Yellow-headed Blackbird, like the other icterid species, flock in winter, so the opportunity for transmission of mites among individuals should be similar. However, of 49 specimens (of 214 total, or 22\%) of the Yellow-headed Blackbird in the two museum collections dated post-1962, after the first outbreak among the Tricolored and Red-winged Blackbirds, none have the condition. This may be due to geographic patterns of mite infestations in the western U.S. Only six of the 34 mite-infested specimens of icterids found with the condition in the two collections are from desert regions (including three Great-tailed Grackles from Arizona). Yellow-headed Blackbirds nest locally in the region, primarily in desert wetlands, and reach the coast as wandering vagrants only (Patten et al. 2003, Jaramillo 2008). As mite infestations appear to be rare in the desert environments, Yellow-headed Blackbirds may escape exposure. Recent observations of urban Brewer's Blackbirds and captures of Brown-headed Cowbirds in desert cities and agricultural areas in the Coachella Valley and Salton Sink in California support the lower prevalence of mite infestations in these environments (Clark pers. obs.). Rosen (1959) reported an outbreak of scaly-leg in the White-winged Dove (Zenaida asiatica) near Calipatria, Imperial County, though columbids are parasitized by some different genera of knemidokoptids so this outbreak may have been due to different mite species.

Latta (2003) and van Velden (2017) suggested a positive relationship with mite infestation and dry climates. We found infestations more prevalent on the coastal slope where humidity and rainfall are higher than in inland desert regions. Latta observed more communal roosting at his drier sites than at higher-elevation moister sites, and suggested this behavior contributes to transmission of the mite among hosts. We know of no difference in roosting behavior in coastal versus desert blackbird populations and suggest that differences in mite infestation may be related to inherent limitations in the suitability of habitat microsites for mites in these regions. It is also noteworthy that our relatively moist coastal locations receive only $25-40 \mathrm{~cm}$ of precipitation per year, while inland desert locations receive $<15 \mathrm{~cm}$ per year. Therefore, both of these areas would be considered dry in comparison to the sites in Latta's study.

In the case of the Red-winged and Tricolored Blackbirds, it is difficult to distinguish any effects at the population level of an increase in mite infestation from the effects of loss of foraging habitat to urbanization. But for Brewer's Blackbird, an urban adapter, knemidokoptiasis may be a leading cause of population decline. In San Diego, for example, the decrease in the average number of Brewer's Blackbirds recorded per party-hour on the Christmas Bird Count from 1971-1982 (9.3) to 2006-2017 (0.86) was 
over $90 \%$ (Figure 5). In the Oceanside count circle, $60 \mathrm{~km}$ to the north, the proportional decrease over the same period was even steeper, over $96 \%$.

The behavior of the Western Meadowlark likewise differs from that of other icterids in the region. This species is restricted to open grasslands throughout the year, and it does not forage in urban or suburban landscapes. It does not roost in tight groups like other blackbirds. Therefore both its initial exposure to mites in human-modified landscapes and its ability to transmit the mites appears to be constrained.

This study demonstrates the utility of museum collections as repositories documenting outbreaks of a pathogen in avian populations in both space and time. We expect other collections to hold specimens with readily diagnosable pathogenic characteristics. Searching these collections would provide a valuable comparison to the geographic and species-specific patterns we observed. This study also points to the importance of continued collecting and preparation of museum specimens, to track changing conditions in regional avifaunas. The recent upsurge in mite-infested specimens since 1962 could be quantified only through the continued efforts to grow these collections.

Our study represents only a small step in any effort to understand the possibly increasing effect of infestation with Knemidokoptes on bird populations. For further research, we recommend

- Review of specimens in more museum collections, especially growing collections with a temporal coverage of decades, up to the present.

- Coverage of a broader geographic area, coupled with better quantification by biogeographic region, by habitat, and by aspects of life history such as sociality and urban adaptation.

- Broader taxonomic coverage, including quantification of incidence in species of birds in decline.

- Investigation of the life history and possible seasonality of Knemidokoptes, and of the modes and sites of its transmission.

- Quantification of mortality due to Knemidokoptes, of the progression of the disease, of its transmission from adult to their young, and of its effect on reproductive success.

- Regular quantification of rates of infestation by bird banders.

- Experiments in treatment, as outlined above. Areas where Tricolored Blackbirds congregate to feed would be especially appropriate, given that species' gregariousness and steep decline, to which Knemidokoptes may be contributing significantly.

- Further effort to collect, specifically identify, and voucher mite specimens is also needed.

\section{ACKNOWLEDGMENTS}

We thank April Gorow for assistance with the clinical examinations of blackbirds. We also thank Eleanor Osgood for assistance in analyzing specimens from the Natural History Museum of Los Angeles County. Robert J. Meese provided valuable discussions on the prevalence of mites in the Tricolored Blackbird. Andrea Ayala provided the reference for the 1953 Pasadena specimen. Our work at Clover Flat was made possible by the California Department of Fish and Wildlife and the Back Country Land Trust. Our work in the San Jacinto Mountains was supported in part by the National Science Foundation under grant 1457521. Any opinions, findings, conclusions, 


\section{PATTERNS IN KNEMIDOKOPTES MITE INFESTATIONS}

or recommendations expressed in this article are those of the authors and do not necessarily reflect the views of the National Science Foundation. We thank reviewers Andrea Ayala and Robert J. Meese for their helpful suggestions.

\section{LITERATURE CITED}

Benkman, C. W., Colquitt, J. S., Gould, W. R., Fetz, T., Keenan, P. C., and Santisteban, L. 2005. Can selection by an ectoparasite drive a population of Red Crossbills from its adaptive peak? Evolution 59:2025-2032; doi 10.1111/j.00143820.2005.tb01071.x.

Brennan, D. S. 2013. Why are blackbirds' feet deformed? San Diego Union-Tribune, 4 March 4 2013; http://www.utsandiego.com/news/2013/mar/03/blackbirdfoot-malady-poses-scientific-mystery/

Carothers, S. W., Sharber, N. J., and Foster, G. F. 1974. Scaly-leg knemidokoptiasis in a population of Evening Grosbeaks. Wilson Bulletin 86:121-124.

Dabert, J., Mihalca, A. D., and Sándor, A. D. 2011. The first report of Knemidokoptes intermedius Fain et Macfarlane, 1967 (Acari: Astigmata) in naturally infected European birds. Parasitol. Res. 109:237-240; doi 10.1007/s00436-011-2390-8.

Fain, A., and Elsen, P. 1967. Les acariens de la famille Knemidokoptidae producteurs de gale chez les oiseaux (Sarcoptiformes). Acta Zool. Pathol. Antverpiensia 45:3-142.

Herman, C. M., Locke, L. N., and Clark, G. M. 1962. Foot abnormalities of wild birds. Bird-Banding 33:191-198; doi 10.2307/4510960.

Jaramillo, A. 2008. Yellow-headed Blackbird, in California Bird Species of Special Concern: A Ranked Assessment of Species, Subspecies, and Distinct Populations of Birds of Immediate Conservation Concern in California (W. D. Shuford and T. Gardali, eds.), pp. 444-450. Studies of Western Birds 1. W. Field Ornithol., Camarillo, CA, and Calif. Dept. Fish and Game, Sacramento.

Kirmse, P. 1966. Cnemidocoptic mite infestations in wild birds. Bull. Wildlife Disease Assoc. 2:86-99; doi 10.7589/0090-3558-2.4.86.

Latta, S. C., 2003. Effects of scaley-leg mite infestations on body condition and site fidelity of migratory warblers in the Dominican Republic. Auk 120:730-743; doi 10.1642/0004-8038(2003)120[0730:EOSMIO]2.0.CO;2.

Munday, T. L. 2006. The search for the reasons causing feet abnormalities in the Cape Wagtail (Motacilla capensis). M.S. dissertation, Univ. of Johannesburg, South Africa.

Patten, M. A., McCaskie, G., and Unitt, P. 2003. Birds of the Salton Sea: Status, Biogeography, and Ecology. Univ. of Calif. Press, Berkeley.

Pence, D. B. 1972. Picicnemidocoptes dryocopae gen. et sp. n. (Acarina: Knemidokoptidae) from the Pileated Woodpecker, Dryocopus pileatus L., with a new host record for Knemidokoptes jamaicensis Turk. J. Parasitol. 58:339-342; doi $10.2307 / 3278100$.

Pence, D. B., Cole, R. A., Brugger, K. E., and Fischer, J. R. 1999. Epizootic podoknemidokoptiasis in American Robins. J. Wildlife Disease 35:1-7; doi 10.7589/ 0090-3558-35.1.1.

Rosen, M.N. 1959. Killing them with kindness. Outdoor California 20:12-13.

Stewart, P. A. 1963. Abnormalities among Brown-headed Cowbirds trapped in Alabama. Bird-Banding 34:199-202; doi 10.2307/4511029.

Turk, F. 1950. A new species of parasitic mite, Cnemidocoptes jamaicensis, a causative agent of scaly-leg in Turdus aurantiacus. Parasitology 40:60-62; doi $10.1017 /$ S003118200001787X.

Unitt, P. 2004. San Diego County bird atlas. Proc. San Diego Soc. Nat. Hist. 39.

Van Velden, J. L., Koeslag, A., Curtis, O., Gous, T., and Amar, A. 2017. Negative effect of mite (Knemidokoptes) infection on reproductive output in an African raptor. Auk 134:498-508; doi 10.1642/AUK-16-134.1. 